\title{
Artemisia annua Leaf Extract Increases GLUT-4 Expression in Type 2 Diabetes Mellitus Rat
}

\author{
Arum Kartikadewi ${ }^{1, *}$, Awal Prasetyo ${ }^{2}$, Lisyani Budipradigdo ${ }^{2}$, Heri Nugroho $^{2}$, \\ Kusmiyati Tjahjono ${ }^{2}$, Arthur Lelono ${ }^{3}$ \\ ${ }^{1}$ Faculty of Medicine, Universitas Muhammadiyah Semarang, Jl. Kedungmudu 18, Semarang, Indonesia \\ ${ }^{2}$ Faculty of Medicine, Universitas Diponegoro, Jl.Prof.H.Soedarto, Semarang, Indonesia \\ ${ }^{3}$ Indonesian Institute of Science (LIPI), Jl. Raya Bogor Km 46, Cibinong, Bogor, Indonesia \\ ${ }^{*}$ Corresponding author. E-mail: arum_kartikadewi@yahoo.com
}

Received date: Aug 31, 2018; Revised date: Oct 29, 2018; Accepted date: Nov 6, 2018

\section{Abstract}

$\mathrm{B}$ ACKGROUND: The depletion of glucose transporter 4 (GLUT-4) affects blood glucose level in the type 2 diabetes mellitus (T2DM) patient. Herbals supplementation such as Artemisia annua is known to posses an antidiabetic potency, but its effect on long term glucose control marker, glicated hemoglobin (HbA1C) and muscle GLUT-4 expression still has not been investigated.

METHODS: Twenty Wistar rats were divided into four groups (five rats per group). The $\mathrm{C} 1$ group was consist of healthy control rats and $\mathrm{C} 2$ group was consist of diabetic control rats. Diabetic condition was induced by giving high lard fat diet for 28 days, followed with $30 \mathrm{mg} / \mathrm{kgBW}$ of Streptozotocin injection at the $29^{\text {th }}$ day. Meanwhile, $\mathrm{T} 1$ and T2 group were consist of diabetic rats, which were supplemented with $50 \mathrm{mg} / \mathrm{kgBW}$ and $100 \mathrm{mg} / \mathrm{kgBW}$ of Artemisia апnиа leaf extract, respectively. GLUT-4 expression and $\mathrm{HbA1C}$ level were measured at the $14^{\text {th }}$ day post-treatment.

RESULTS: The GLUT- 4 was expressed 1.8 and two times higher in $\mathrm{T} 1$ and $\mathrm{T} 2$ group, respectively, compared to $\mathrm{C} 2$ group. Meanwhile, $\mathrm{HbA1C}$ level in $\mathrm{C} 2$ group was two times higher than $\mathrm{C} 1$ group (11.95 \pm 2.52 compared to $5.61 \pm 2.69, p<0.01)$. Further, the administration of $100 \mathrm{mg} /$ $\mathrm{kgBW}$ Artemisia annua extract caused a slight reduction of HbA1C (11.95 \pm 2.52 compared to $8.18 \pm 3.53, p>0.05$ )

CONCLUSION: Muscle cell's GLUT- 4 in T1 and T2 group was expressed increasingly and significantly different compared to the $\mathrm{C} 2$ group. $\mathrm{HbA} 1 \mathrm{C}$ level in $\mathrm{T} 2$ was slightly reduced although no significant different compared to $\mathrm{C} 2$ group.

KEYWORDS: Artemisia annua, GLUT-4, HbA1C, type 2 diabetes mellitus

Indones Biomed J. 2019; 11(1): 78-84

\section{Introduction}

Type 2 diabetes mellitus (T2DM) is a condition, which insulin is unable to bind the receptor on dependent-insulincells of liver, muscle and adipose. In 2010, there are more than 300 milion DM prevalence, and it is predicted to be double in 2030.(1)

Under the T2DM condition, there are several process in alteration glucose transporter 4 (GLUT-4) formation. GLUT-4 is a special transporter located mostly in striated muscle. This transporter facilitates glucose influx and utilization. Long term high fat diet increases radical oxidant and inflammation that induces glucolipotoxicity and islet cell apoptosis. This condition decreases insulin secretion and reduces signaling pathway of GLUT-4 formations. Reduced activities of GLUT-4 signaling pathway interferes with pheripheral glucose utilization and affects bloodglucose control which marked by high level of glicated haemoglobin (HbA1C). In further condition, uncontrolled long term blood glucose will increase the complication of chronic T2DM and organs failure. $(2,3)$ 
The complexity of T2DM pathogenesis, encourage researcher to invent and develop new drugs research. The new drug is expected to be able to improve GLUT-4 function, so, it can maintain long term glucose control that caused by high fat intake and insulin resistance. Nowadays, World Health Organization (WHO) promotes research to investigate new T2DM drugs from natural herbs because of their multiple target therapy and safeties.(4-6)

Artemisia annua was previously used as antimalarial, however it also proven to have antidiabetic potency. Previous research documented that an administration of $28.5 \mathrm{mg} / \mathrm{kgBW}$ twice/day Artemisia anпиa leaf extract for 2 weeks on alloxan-induced rats, reduces fasting blood glucose (FBG), increases insulin production and decreases homeostasis model assessment for insulin resistance (HOMA-IR).(7) The purified extract of $83.56 \mathrm{mg} / \mathrm{kgBW}$ of Artemisia annua is better for lowering FBG.(8) Artemisia аппиа contains squiterpen, coumarin and flavonoids, which have multi-target therapy as antidiabetic. However, more information related to the expression of GLUT-4 in muscle tissue and $\mathrm{HbA1C}$ mediating high fat diet needs to be carried out. Hence, this research is aimed to prove the effect of Artemisia annua leaf extract on muscle GLUT-4 expression and $\mathrm{HbA} 1 \mathrm{C}$ level in T2DM caused by high fat diet condition.

Methods

This was an experimental post test control only study that was conducted in Universitas Gadjah Mada for three months. Ethical approval was obtained from Medical Research Ethic Committee Universitas Diponnegoro-Kariadi Hospital, Number 967/EC/FK RSDK/IX/2016.

\section{Experimental Protocol (Animal Treatment)}

Twenty 6-8 weeks-old-male Wistar rats weighed 150200 grams was obtained from Center of Inter-University Laboratory of Universitas Gadjah Mada. The rats were divided into four groups, which each group consist of five rats. Every single rats were placed individually in separated cages. They were housed under normal room temperature $25 \pm 2^{\circ} \mathrm{C}, 50 \pm 12 \%$ of humidity and 12 hours of photoperiod cycles. Each cages were provided with standard diet and water ad libitum.

The groups consist of healthy control group ( $\mathrm{C} 1$ group) which was given standard diet, and diabetic control group (C2 group) that was administered with placebo. Then, diabetic treatment groups which supplemented with $50 \mathrm{mg} /$
$\mathrm{kgBW}$ of Artemisia annua leaf extract (T1 group) and 100 $\mathrm{mg} / \mathrm{kgBW}$ of Artemisia annua leaf extract (T2 group).

\section{T2DM Induction}

Diabetic rats (C2, T1 and T2 group) were induced using lard $20 \%$ of rats' total calory diet for about 28 days, through intragastric sonde, followed by $30 \mathrm{mg} / \mathrm{kgBW}$ of streptozotocyn that were injected intraperitoneally. (9) T2DM condition was determined by FBG level (more than $140 \mathrm{mg} / \mathrm{dL}$ at $36^{\text {th }}$ day).(9) Treatment group were supplemented with Artemisia annua leaf extract at dose 50 $\mathrm{mg} / \mathrm{kgBW}$ and dose $100 \mathrm{mg} / \mathrm{kgBW}$ for 14 days treatment after streptozotocyn treatment (day 36 until day 50). Artemisia annua leaf extract was given orally to gastric, to avoid drug-food interaction.(10)

\section{Extract Preparation}

Artemisia anпиа extract was made from five $\mathrm{kg}$ of the plant's leaf. The leaf was dried at $40^{\circ} \mathrm{C}$ using oven for three days. About 100 gr dried leaves was grinded until they became powder, then boiled in $1 \mathrm{~L}$ of sterriled water at $60^{\circ} \mathrm{C}$ for 30 minutes. The extract was cooled at room temperature and filtered using Whatman ${ }^{\circledR}$ quantitative filter paper, ashless, Grade 41 (Merck, Darmstadt, Germany). The liquid concentrate extract was heated in cabinet dryer at $40^{\circ} \mathrm{C}$ for an hour.(11) The final extract obtained was as much as 16.4 gr. Spectrophotometry analysis was conducted to measure the wavelength of extract and to determine the contained compound.

\section{Muscle GLUT-4 and HbA1c Analysis}

Blood collection was conducted at the $50^{\text {th }}$ day using hematocrit from plexus retroorbita. Collected blood was placed in the $2 \mathrm{~mL}$ sterile ethylenediaminetetraacetic acid (EDTA) tube. After that, all rats were sacrificed, and the gastrocnemous muscle were collected for immunohistochemistry analysis of GLUT-4 expression. The GLUT-4 expression scale was examined based on Allred scoring that observed by Anatomy Pathologist expert, microscopically. The Anatomy Pathologist examined five field areas using 400x magnificence lens and then scored to analyze. Collected blood was centrifuged at 8000 RPM for eight minutes to separate blood composition. The plasma was used to measure $\mathrm{HbAlC}$ by high performance layer chromatography. (12)

The GLUT-4 Allred score and HbA1C level were analyzed statistically using one way ANOVA, followed by fisher exact Least Significant Difference (LSD) using SPSS 21 for windows. 


\section{Results}

The extraction yielded 16.9 gram of paste extract. Artemisia апnиа leaf extract was measured using spectrophotometry wavelength $>310 \mathrm{~nm}$ and $>270 \mathrm{~nm}$ for band I and II. After measurement, the extract indicated that it contained flavonoid compound inside.

\section{Blood Glucose during Fasting and Post Prondial}

After streptozotocyn injection, FBG level in diabetic rats (C2, T1 and T2) was increased beyond the FGB level of $\mathrm{C} 1$ group. The highest FBG concentration was measured in T2 group $(195.26 \pm 3.58 \mathrm{mg} / \mathrm{dL})$ followed by T1 group, (193.66 $\pm 2.19 \mathrm{mg} / \mathrm{dL})$, and lastly was $\mathrm{C} 2$ group eventhough was not significantly different $(191.08 \pm 2.29 \mathrm{mg} / \mathrm{dL})$. Based on those conditions, all rats in diabetic induction have FBG concentration more than $140 \mathrm{mg} / \mathrm{dL}$, which indicating a succesfull diabetic induction. $\mathrm{T} 1$ and $\mathrm{T} 2$ groups were administrated with Artemisia annua leaf extract for 14 days, then the FGB concentration was remeasured to determine the blood glucose condition. Based on the analysis, there were lowered blood glucose in all diabetic rats. The highest depression in T2 group, which was $44.6 \%$ to $108.20 \pm 2.62$ $\mathrm{mg} / \mathrm{dL}$. It was significantly different to $\mathrm{T} 1$ group with $32.32 \%$ depression and $131.50 \pm 2.62 \mathrm{mg} / \mathrm{dL}$ level of blood glucose. Meanwhile, blood glucose in C2 group was depressed as much as $0.3 \%$, to $191.72 \pm 2.29 \mathrm{mg} / \mathrm{dL}$ (Table 1 ).

On the other hand, post prandial blood glucose that represent the glucose concentration that circulated in periferal blood stream (glucose in blood vessel) in diabetic group increased beyond normal level (Table 2). After 100 $\mathrm{mg} / \mathrm{kgBW}$ of Artemisia annua leaf extract administration, the post prandial blood glucose sharply went down in T2 group up to $45.5 \%$ from $204.98 \pm 3.15 \mathrm{mg} / \mathrm{dL}$ to $111.94 \pm 2.41$ $\mathrm{mg} / \mathrm{dL}$. It was significantly different to other groups $(\mathrm{C} 1$,
$\mathrm{C} 2$ and T1). In T1 group, the blood glucose decreased as much as $34.3 \%$ from $204.58 \pm 2.24 \mathrm{mg} / \mathrm{dL}$ to $134.73 \pm 2.01$ $\mathrm{mg} / \mathrm{dL}$. But, both in T1 and $\mathrm{T} 2$ were decresed higher than $\mathrm{C} 1(0.08 \%)$ and $\mathrm{C} 2$ (2.9\%) (Table 2).

\section{Effect of Artemisia annua Extract to HbA1C}

$\mathrm{HbA1C}$ level gives better understanding about long term blood glucose control in diabetic condition. The HbA1C in $\mathrm{C} 2$ group was $11.95 \pm 2.52 \mathrm{mg} / \mathrm{dL}$, it was higher and significantly different compared to $\mathrm{C} 1$ group, $5.61 \pm 2.69$ $\mathrm{mg} / \mathrm{dL}(p<0.01)$. Furthermore, administration of $100 \mathrm{mg} /$ $\mathrm{kgBW}$ of Artemisia annual extract in $\mathrm{T} 2$ group slightly reduced $\mathrm{HbA} 1 \mathrm{C}$ level at $8.18 \pm 3.53 \mathrm{mg} / \mathrm{dL}$, although it is not significantly different with $\mathrm{C} 2$ group. Administration of 50 $\mathrm{mg} / \mathrm{kgBW}$ can not reserve diabetic codition $(\mathrm{HbA} 1 \mathrm{C}$ level $=$ 11.16 \pm 2.52 ) (Figure 1).

\section{Effect of Artemisia annua to GLUT-4 Protein Expression in The Muscle}

To understand the mechanism underlying the ability of Artemisia annua extract to reverse T2DM state, we examined the muscle GLUT-4 expression post extract treatment (Figure 2). DM rats experienced 50\% reduction in the muscle GLUT-4 expression, which was confirming the T2DM state that previously confirmed in the HbA1c studies. The administration of Artemisia annua extract for 14 days increased muscle GLUT-4 expression by 1.8 and two fold by using $50 \mathrm{mg} / \mathrm{kgBW}$ and $100 \mathrm{mg} / \mathrm{kgBW}$, respectively. Interestingly, the level of GLUT-4 expression after $100 \mathrm{mg} / \mathrm{kgBW}$ administration of the extract reversed the GLUT-4 expression into normal level as we did not see significant difference of GLUT-4 expression between healthy and diabetic rats treated with $100 \mathrm{mg} / \mathrm{kg} \mathrm{BW}$ extract. Furthermore, there was a trend of concentration dependent on the ability of the extract improving the GLUT4 expression.

Table 1. FBG level in T2DM rats before induction, post induction and post treatment conditon.

\begin{tabular}{|c|c|c|c|c|}
\hline Group & $\begin{array}{l}\text { Before Induction } \\
\text { (BI) (mg/dL)* }\end{array}$ & $\begin{array}{l}\text { Post Induction } \\
\text { (PI) (mg/dL) }\end{array}$ & $\begin{array}{l}\text { Post Treatment } \\
\text { (PT) (mg/dL) }\end{array}$ & (PT-PI) (\%) \\
\hline $\mathrm{C} 1$ & $59.91 \pm 1.01$ & $61.68 \pm 1.08^{\mathrm{a}}$ & $62.93 \pm 1.19^{\mathrm{a}}$ & $1 \uparrow$ \\
\hline $\mathrm{C} 2$ & $57.26 \pm 1.83$ & $191.08 \pm 2.29^{b}$ & $191.72 \pm 2.29^{b}$ & $0.3 \uparrow$ \\
\hline $\mathrm{T} 1$ & $56.66 \pm 2.15$ & $193.66 \pm 2.19^{\mathrm{bc}}$ & $131.50 \pm 2.62^{\mathrm{c}}$ & $32.12 \downarrow$ \\
\hline $\mathrm{T} 2$ & $56.41 \pm 1.78$ & $195.26 \pm 3.58^{\mathrm{c}}$ & $108.20 \pm 2.62^{\mathrm{d}}$ & $44.6 \downarrow$ \\
\hline
\end{tabular}

*no significant different; alphabetic labels (a-d) represent significant differencies of mean value among each groups. 
Table 2. Post prandial blood glucose level in T2DM rats before induction, post induction and post treatment conditon.

\begin{tabular}{ccccc}
\hline Group & $\begin{array}{c}\text { Before Induction } \\
(\mathbf{B I})(\mathbf{m g} / \mathbf{d L})^{*}\end{array}$ & $\begin{array}{c}\text { Post Induction } \\
(\mathbf{P I})(\mathbf{m g} / \mathbf{d L})\end{array}$ & $\begin{array}{c}\text { Post Treatment } \\
(\mathbf{P T})(\mathbf{m g} / \mathbf{d L})\end{array}$ & (PT-PI) (\%) \\
\hline $\mathrm{C} 1$ & $65.91 \pm 1.17$ & $67.87 \pm 1.63^{\mathrm{a}}$ & $67.30 \pm 0.81^{\mathrm{a}}$ & $0.08 \downarrow$ \\
$\mathrm{C} 2$ & $62.82 \pm 2.17$ & $201.04 \pm 2.81^{\mathrm{b}}$ & $195.02 \pm 2.09^{\mathrm{b}}$ & $2.9 \downarrow$ \\
$\mathrm{T} 1$ & $62.65 \pm 2.64$ & $204.58 \pm 2.24^{\mathrm{b}}$ & $134.73 \pm 2.01^{\mathrm{c}}$ & $34.3 \downarrow$ \\
$\mathrm{T} 2$ & $62.65 \pm 1.37$ & $204.98 \pm 3.15^{\mathrm{b}}$ & $111.94 \pm 2.41^{\mathrm{d}}$ & $45.5 \downarrow$ \\
\hline
\end{tabular}

*no significant different; alphabetic labels (a-d) represent significant differencies of mean value among groups.

\section{Discussion}

In this research, the administration of high lard fat diet followed by streptozotocin injection increased the blood glucose and represented T2DM condition. High fat diet will induced peripheral insulin resistance, by activating kinase protein $\mathrm{C}$ (PKC) and fight the function of insulin receptor substrate (IRS). $(13,14)$ Low dose streptozotocyn injection makes partial destruction of islet cell of pancreatic organ. This condition triggers relative hyperinsulinemia, high blood glucose and hyperlipidemia just like T2DM. Hyperlipidemia induces oxidative stress condition and inflammation, which induce alteration of GLUT-4 formation and function. Insulin resistant then disruptes peripheral glucose utilization.(9)

Current researches indicate that T2DM's effect is able to be reduced by herbals supplementation. In this research, the used herbal, Artemisia annua leaf extract, was

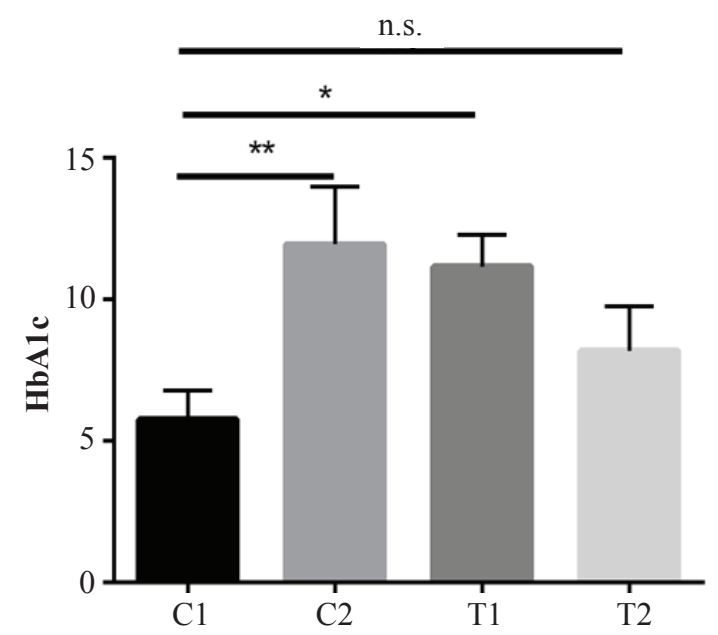

Figure 1. The level of $\mathrm{HbA1C}$ in DM rats post treatment. Rats were treated with Artemisia annua leaf extract after 14 days. ${ }^{*} p<0.05 ; * * p<0.0001$; n.s.: not significant. significantly reduced high glucose levels. It is supported with previous research which proved that there was a reduction of FBG level in alloxan-induced rats that were given $28.5 \mathrm{mg} /$ $\mathrm{kgBW}$ of Artemisia annua twice per day for 2 weeks. It also increased the insulin production and decreased homeostasis of model assessment for insulin resistance (HOMA-IR).(7) The purified extract of $83.56 \mathrm{mg} / \mathrm{kg}$ BW Artemisia annиа was better in lowering FBG.(8)

Although some studies confirmed about the antidiabetic potency of Artemisia annua, there is still no information available related to expression of GLUT-4 in muscle tissue. During insulin signaling, when insulin attaches to receptor dimer, the receptor experiences auto phosphorylation which is recognized by PKC. This phosphorylated form is called IRS. The IRS then recruits phosphatidil inositol kinase 3 (PI3K) that bind to Protein kinase B (Akt) molecules as its downstream signaling. PI3K/Akt is the pathways that been known to regulates GLUT-4 expression.(15)

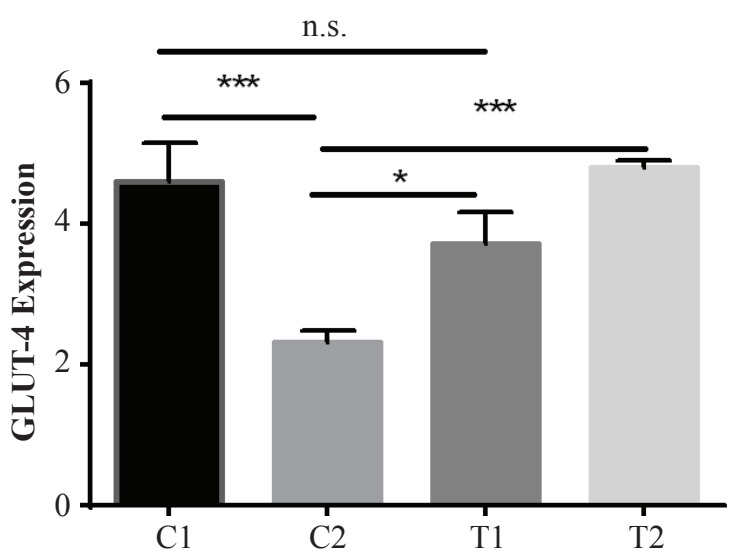

Figure 2. Muscle GLUT-4 expression examined using immunohistochemistry post treatment. Artemisia annua leaf extract reverse the depletion of GLUT- 4 in the diabetic condition as there is an increased in GLUT-4 expression. ${ }^{*} p<0.05$; *** $p<0.0001$; n.s.: not significant. 

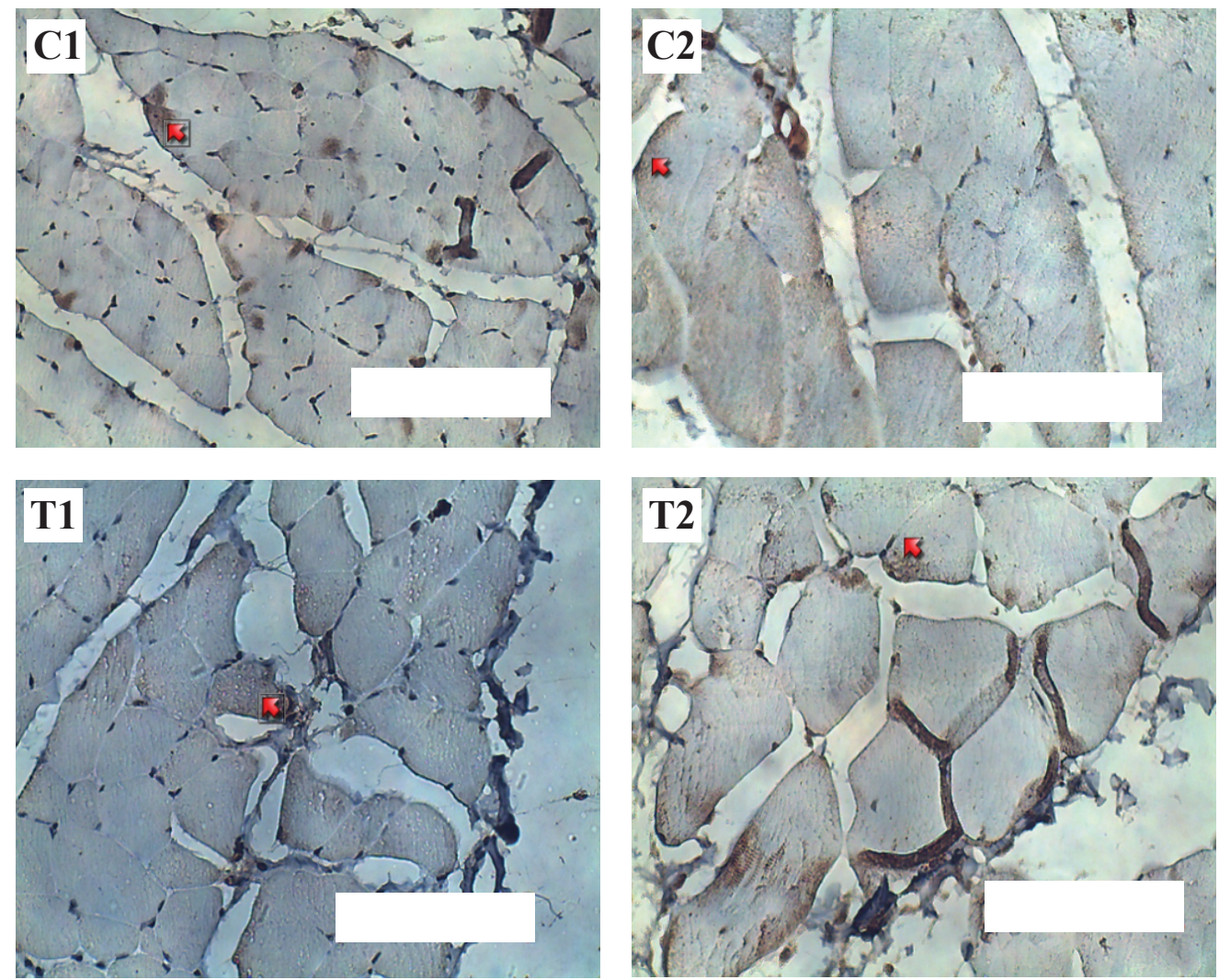

Figure 3. Muscle GLUT-4 expression in muscle cells. GLUT-4 protein expressed at muscle cell membran and cytoplasmic as brown coloured. Intensed colour indicated more GLUT-4 expression. C1: (Average Allred: 4.6), arrows indicated strong intensity and percentage of cells expressing as much as 30\%; C2: (Average Allred: 2.32), arrows indicated weak intensity with percentage of cells expressing GLUT4 by 20\%; T1: (Average Allred: 3.72), arrows indicated strong intensity and percentage of expressing cells as much as 20\%; T2: (Average Allred: 4.8), arrows showed moderate intensity with the percentage of cells that express GLUT-4 as much as $60 \%$. Muscle cell in passage observed with light microscope. White bar: $100 \mu \mathrm{m}$.

Beside via insulin signaling pathways, GLUT4 expression might also regulated by adenosine monophosphate-activated protein kinase (AMPK). Muscle activity and muscle volume influence AMPK activity that favor the GLUT-4 translocation.(16) GLUT-4 expression is also influenced by acute or chronic changes of osmolarity and physical stress. Acute stress increases GLUT-4 expression temporary, while chronic stress decreases GLUT-4 expression.(17)

Glycolipotoxicity occur in diabetic condition (C2 group). Glycolypotoxicity causes oxidative stress and inflammation that alters the phosphorylation of the IRS. Instead of phosphorylated by tyrosine, IRS become a subject of serine-threonine phosphorylation. This molecule deregulate PI3K downstream signaling and the ability to translocate GLUT-4. In T2DM, 90\% insulin signal which promotes GLUT-4 translocation was diminished. On the other hand, AMPK only contributed to $30 \%$ of GLUT-4 translocation. This leads to the decline of GLUT-4 expression under T2DM state.(14,18)
In our studies, the administration of $100 \mathrm{mg} / \mathrm{kg}$ BW of Artemisia annua leaf extract at dose (T2 group) improved GLUT-4 expression. Artemisia anпиа contains phenolic flavonoid derivatives compound which may increase peripheral glucose influx. Some flavonoid derivates potentially increase glucose utilization by several mechanism, for example epigallocathein gallate (ECGC) increased insulin action via glucose utilization. The other compounds, kaemfetrin increased GLUT-4 translocation and synthesis in adipose cell and tissue. Quercertin, a flavonoid, increased the expression of GLUT-4 mRNAs and its translocation. ECGC, hisperidin and nangerin also increase GLUT-4 translocation in muscle and adipose cell membranes. Flavonoids derivates promote GLUT-4 muscle translation from PI3K pathway. In addition, flavonoids also activate GLUT-4 translocation through AMPK pathway.(6)

Other study stated that ethanol extract of Artemisia princeps increases glucose uptake by mediating GLUT4 translocation in myocite cell line.(19) Ethanolic extract 
of Artemisia dracunculus L enhance insulin receptor signaling, but not increase gen signaling of IRS-1, PI3K and GLUT-4 tanslocation. This condition due to proteosome degradation and ubiquitin conjugation which reduce gene expression.(20)

However, it is better to figure out the successfulness of its therapy. Since the research itself is unable to detect the $\mathrm{HbA} 1 \mathrm{C}$ changes due to the difference during treatment length (14 days), compared to the Wistar rat erythrocytes age (59 days). Glycemic reactions in $\mathrm{HbA} 1 \mathrm{C}$ measurement occur in the $1^{\text {st }}$ month of the end of the erythrocyte life cycle.(21) About 50\% HbA1C levels reflect blood glucose levels in the last 30 days of erythrocyte life cycle. About $25 \% \mathrm{HbA} 1 \mathrm{C}$ levels reflect the first 60 -day blood sugar level of the erythrocyte life cycle. HbA1C reflects erythrocyte glycation for 117 days in men and 106 days in women. (22) The study will be better if long term glucose control parameter use glicated albumin. This parameter reflects glucose control for approximately three weeks.(23)

More efficient extraction technique is needed in this studies to improve the artemisinin content in the extract. Infuse might be potential. It is developed from 9 grams of dried leaves which result in $94 \mathrm{mg}$ artemisinin. In term of pharmacokinetics standpoint, artemisin plasma concentration is $3.36 \mathrm{~nm} / \mathrm{mL}$ with the half-life about 2.4 hours. After 8 hours, the level of artemisinin will be eliminated. With this ratio, to achieve optimal plasma levels, the extract should be administrated more than once a day.(24)

The active compound in the Artemisia annua extract that poses an action to reduced blood glucose is unknown. But, Artemisia annua is one of the plants that contain high levels of flavonoids. Flavonoids generally have antidiabetic activity in the form of revitalization and stimulation of pancreatic $\beta$ cells in the release of insulin, increasing the sensitivity of insulin receptors or insulin like peptide, preventing glycogen breakdown, increasing glucose utilization at peripheral tissue, promote free radical clearance, and improve microcirculation.(25)

Besides that, the extract contains artemisinin, polyphenols, flavonoids, vitamins $\mathrm{C}$ and $\mathrm{E}$ which are antioxidants.(26) Flavonoids in the extract has an antioxidant effect. Antioxidants will prevent oxidative stress so it will prevent pancreatic $\beta$ cell death, thus improving insulin secretion. Decreased oxidative stress will also improve insulin action in peripheral glucose utilization and prevent glycogenolisis from the liver. When insulin actions appropriate, fasting blood sugar and postprandial blood sugar will be well controlled. Glucose levels will be maintained within the normal range which will further decrease glycemic erythrocytes emitted from $\mathrm{HbAlC}$ levels.(27)

A study of 38,018 women which at risk of T2DM, differences dietary flavonoid consumption patterns in 8-yearold observations, was associated with a decrease in the risk of T2DM. The difference in the amount of consumption of flavonoid was not significantly associated with $\mathrm{HbA1C}$ decline, fasting insulin concentration, interleukin-6 (IL-6) and $\mathrm{C}$-ractive protein (CRP). These results are possible due to differences in group characteristics. Each group has a habit of smoking, alcohol, exercise, diet, fat-carbohydrate intake, blood glucose fluctuation and history of other diseases of different metabolic syndrome.(28)

This study proves that giving Artemisia annua leaf extract to T2DM rats improves muscle GLUT-4 expression and slightly lowers $\mathrm{HbA} 1 \mathrm{C}$ as the goal of long term glycemic control in DM.

There are some limitations of this study. Total flavonoid content for dose standardization has not been measured. Determination of doses in this study only based on previous research. Lenght of treatment is also too short, about 14 days, whereas $\mathrm{HbA1C}$ is a parameter of controlling long-term blood sugar levels whose value corresponds to Wistar erythrocyte age about 59 days. This study also has not measured the factors of kidney damage, liver and possible anemia in rats that are likely to affect the interpretation of $\mathrm{HbA} 1 \mathrm{C}$ measurements.(25)

Further research are still needed to find out the active flavonoid content to standard the dosage. Research should measure the effect of the various levels of dosage. Research on acute, sub-chronic and chronic toxicity is also required for the development of Artemisia annua research as an herbal remedy for T2DM. More research using better parameter of long term blood glucose control using more preferable variabel.

\section{Conclusion}

Muscle cell's GLUT-4 in T1 and T2 group was expressed increasingly and significantly different compared to $\mathrm{C} 2$ group. HbA1C level in T2 group was slightly reduced although there was found no significant different compared to diabetic control. 


\section{Acknowledgement}

We would like to thank the staff of Botanical Gardens Cibodas LIPI who provides Artemisia annua herbs. We also want to thank the staff of the Food and Nutritions Laboratory of Gadjahmada University, Anatomy Pathology Laboratory of Radioputro, Anatomy Pathology Laboratory of Sardjito Hospital Yogyakarta for all research assistance, and to Marlyn Laksitorini for the insight discussion of this paper.

\section{References}

1. Wild S, Rocglig G, Green A, Sicree R, King. Global prevalence of diabetes: estimates for the year 2000 and projections for 2030. epidemiology health service physicosocial research. Dia Care. 2004; $27: 1-7$.

2. Poitout V. Glucolipotoxicity of the pancreatic beta-cell: myth or reality? Biochem Soc Trans. 2008; 36: 901-4.

3. Katsumata K, Kaji Y, Takada R, Dauncey J. Nutritional regulation of GLUT expression, glucose metabolism, and intramuscular fat content in procein muscle. Asian Aust J Anim Sci. 2007; 20: 1297304.

4. Nathan D, Buse JB, Davidson MB, Heinei RJ, Holman RR, et al. Management of hyperglicaemia in type 2 diabetes: a consensus and algorithm for initial and adjustment therapy. Diacare. 2006; 29: 1963-73.

5. Tripathi BK, Srivastava AK. Diabetes mellitus: complication and therapeutic. Med Sci Monit. 2006; 12: 130-47.

6. Xiao J. Phytochemicals in medicine and food. Phytochem Rev. 2015; 14: 317-20.

7. Helal EG, Abu-Aouf N, KhatabMA. Antidiabetic effect of arthemisia annua (Kaysoom) in alloxan-induced diabetic rat. Egyptian J Hospital Med. 2014; 57: 422-43.

8. Herlyanti K, Franyoto YD, Sulistyowati E. Pengaruh kombinasi ekstrak terpurifikasi herba Artemisia annua (L) dan herba andrographis paniculata (Burn f)Nees) terhadap kadar glukosa darah pada tikus resisten insulin. Jurnal Ilmu Farmasi dan Farmasi Klinik. 2014; 11: 27-31.

9. Zhang M, Xiao-Yan, Li J, Xu Z, Chen L. Research article the characterization of high-fat diet and multiple low-dose Streptozotocin induced tipe 2 diabetes rat model. Experimental Diabetes Resc. 2008: 1: 704045. doi: 10.1155/2008/704045.

10. Granneman JG, Stricker EM. Food intake and gastric emptying in rats with Streptozotocin-induced diabetes. Am J Physiol. 1984; 247: R1054-61.

11. Sunmonu TO, Afolayan AJ. Evaluation of antidiabetic activity and associated toxicity of Artemisia afra aqueous extract in Wistar rats. Evidence-based Complement Altern Med. 2013; 2013: 929074. doi: $10.1155 / 2013 / 929074$.

12. World Health Organization. Use Glicated Hemoglobin (HbA1C) in the Diagnosis Diabetes Mellitus. Geneva: World Health Organization;
2011.

13. Wilson CH, Ali ES, Scrimgeour N, Martin AM, Hua J, Tallis GA, et al. Steatosis inhibits liver cell store-operated $\mathrm{Ca} 2+$ entry and reduces $\mathrm{ER} \mathrm{Ca} 2+$ through a protein kinase $\mathrm{C}$-dependent mechanism. Biochem J. 2015; 466: 379-90.

14. Boden G, Homko J, Barero CA, Stein TP, Chen X, Cheung P, et al. Excessive caloric intake acutely causes oxidative stress, GLUT4 carbonylation, and insulin resistance in healthy men. Sci Transl Med. 2015; 7: 304re7. doi: 10.1126/scitranslmed.aac4765.

15. Watson RT, Pessin JE. Bridging the GAP between insulin signaling and GLUT4 translocation. Trends Biochem Sci. 2006; 31: 21522.

16. Gaster M, Staehr P, Beck-Nielsen H, Schrøder HD, Handberg A. GLUT4 is reduced in slow muscle fibers of type 2 diabetic patients: is insulin resistance in type 2 diabetes a slow, type 1 fiber disease? Diabetes. 2001; 50: 1324-9.

17. Huang S, Czech MP. The GLUT-4 glucose transporter. Cell Metab. 2007; 3: 237-52.

18. Leguisamo N, Lehnen AM, Machado UF, Okamoto MM, Markoski MM, Pinto GH, et al. GLUT-4 content decreases along with insulin resistance and high levels of inflammatory markers in rats with metabolic syndrome. Cardiovasc Diabetol. 2012; 11: 100. doi: 10.1186/1475-2840-11-100.

19. Yamato N, Ueda M, Kawabata K, Sato T, Kawasaki K, Hashimoto $\mathrm{T}$, et al. Artemisia pinceps promoted glucose uptake in culture L6 muscle cell via glucose transporter 4 translocation. Biosci Biotechnol Biochem. 2010; 74: 2036-42.

20. Wang ZQ, Ribniky D, Zhang XH, Zuberi A, Raskin I, Yu Y, et al. An extract of Artemisia dracunculus L. enhances insulin receptor signaling and modulates gene expression in skeletal muscle in kkay mice. J nutr biochem. 2011; 22: 71-8.

21. Derelanko MJ. Determination of erythrocyte life span in F-344, Wistar, and Sprague-Dawley rats using a modification of the $[3 \mathrm{H}]$ diisopropylfluorophosphate ([3H]DFP) method. Fundam Appl Toxicol. 1987; 9: 271-6.

22. Nathan DM, Turgeon H, Regan S. Relationship between glycated haemoglobin levels and mean glucose levels over time.Diabetologia. 2007;50(11):2239-44

23. Freitas PAC, Elhert LR, Camargo JL. Glycated albumin: a potential biomarker in diabetes. Arch Endocrinol Metab. 2017; 61: 294-314.

24. Räth K, Taxis K, Walz G, Gleiter CH, Li SM, Heide L. Pharmacokinetic study of artemisinin after oral intake of a traditional preparation of Artemisia annua 1. (annual wormwood). Am J Trop Med Hyg. 2004; 70: $128-32$.

25. Little R, Roberts WL. A review of variant hemoglobins interfering with hemoglobin A1c measurement. J Diabetes Sci Technol. 2009; 3: 446-51.

26. Babua AV, Liub B, Gilbertc ER. Recent advances in understanding the anti-diabetic actions of dietary flavonoids. J Nutr Biochem. 2013; 24: 1777-89.

27. Ferreira JFS, Luthria DL, Sasaki T, Heyerick A. Flavonoids from Artemisia annua L. as antioxidants and their potential synergism with artemisinin against malaria and Cancer. Molecules. 2010; 15: 3135-70.

28. Song Y, Manson JE, Buring JE, Sesso HD, Liu S. Associations of dietary flavonoids with risk of type 2 diabetes, and markers of insulin resistance and systemic inflammation in women: a prospective studyand cross-sectional analysis. J Am Coll Nutr, 2005; $24: 376-84$. 